\title{
The biotechnological potential of tomato torch, growing in Dagestan
}

\author{
(C) Saida S. Saidova \\ Dagestan State Technical University. Imam Shamil Ave., $70 \mathrm{~A}$. \\ Makhachkala, 367026. Republic of Dagestan. Russia.
}

Keywords: biotechnology, potential, tomato Torch, hybrid, fertilizers, productivity, fruit quality.

\begin{abstract}
The article explores the biotechnological potential of growing Torch tomatoes in the territory of Dagestan; The characteristics of the hybrid varieties of tomatoes Torch are given. The comparative characteristic of yield indicators of tomato varieties Torch with other varieties cultivated in the southern part of Russia is presented; as part of the field experiment, five universal soil fertilizer schemes and their application regimes for growing tomatoes were tested; the most optimal ratios of the application of nitrogen, phosphorus and potassium for fertilizing soils and fertilizing plants, as an alternative to natural organic nitrogen fertilizers; it is proved that with the introduction of mineral fertilizers against the background of the aftereffect of manure in the soil, the content of nitrates, mobile phosphorus and exchange potassium increases; the influence of the timing of the use of fertilizers on the accumulation of dry matter and the area of the assimilation surface of tomatoes of the Torch variety during the growing season was studied; the dependence of the yield of commodity fruits of the Torch tomato on the doses and timing of the use of fertilizers was established; the effect of fertilizers on individual biometric indicators of Torch tomato plants on the period of mass ripening of fruits is shown; individual indicators of the quality of the Torch tomato fruit in full ripeness are determined depending on fertilizers; it has been shown that the application of fertilizers ensures the yield of fruits of sown tomatoes of the Torch cultivar at the level of 480-500 centner, and also that the tomato plants of the Torch cultivar form the maximum assimilation surface during the period of mass fruit formation; It is shown that the amount of nitrates in the fruits, regardless of the background of cultivation, does not exceed their maximum permissible concentration; in practice, the high yield of tomatoes Torch cultivar in the climatic conditions of Dagestan has been proved.
\end{abstract}

\section{References}

[1] A.A. Autko, I.P. Kozlovskaya. Combined tomato nutrition system with low-volume culture. Vegetable growing and greenhouse farming. 2005. No.1. P.27-29. (russian)

[2] V.A. Bogdanov, S.Yu. Savostyanik. The influence of a set of technological methods on the weediness of crops and crop yields. Nizhny Novgorod. 2017. P.40-42. (russian)

[3] D.N. Brinchuk. More tomatoes, good and different. Gavrish. 2015. No.2. P.6-17. (russian)

[4] S.F. Gavrish, T.A. Naumenko. Varieties, hybrids, technologies in modern greenhouse production. Gavrish. 2015. No.6. P.5-15. (russian)

[5] V.V. Gamayunova, M. Kuts. Growth in the aerial mass of tomatoes and photosynthetic potential depending on growing conditions. Tauride Scientific Bulletin. Kherson. 2014. Iss.32. P.48-54. (russian)

[6] R.A. Guiche, G.S. Ginkalo. Vegetable growing in the south of Russia [Text]: textbook. Krasnodar: EDVI. 2012. 632p. (russian)

[7] M. Gospodarenko. The basic principles of building a fertilizer system in a field crop rotation. Kharkov. 2012. Book 3. P.200-202.

[8] Z.M. Daurov. Technological methods for increasing productivity and optimizing the mineral nutrition regimes of indeterminate tomato hybrids in winter greenhouses of the North Caucasus: Abstract. dis. Cand. S.-kh. sciences. Vladikavkaz. 2008. 23p. (russian)

[9] N.V. Dolgopolova. Optimization of the mineral nutrition of tomato in the seedlings of the sheltered soil in the conditions of the Central Black Earth Region: report on research work. Belgorod. 2015. 99p. (russian)

[10] F. Kiver, I.M. Stepanova. Influence of fertilizers on the yield and quality of sowing tomato fruits in the conditions of the beer climate. Collection of scientific works of the Institute of Agriculture of the southern region. Kherson. 2012. No.3. P.53-55. 
[11] E.G. Kipaeva. Resource-saving elements of tomato cultivation technology in seed crops during irrigation [Text]: dis. ... cand. S.-kh. Sciences. Astrakhan. 2009. 130p. (russian)

[12] F.M. Merzlyakova. Features of the varietal technology of new indeterminate tomato hybrids in the winter-spring and summer-autumn turns of winter greenhouses in the Urals: author. dis ... cand. S.-kh. sciences. Izhevsk. 2005. 20p. (russian)

[13] Description and characteristics of tomato varieties "Torch" [Electronic resource]. Access Mode: https://rusfermer.net/ogorod/plodovye-ovoshhi/tomat-pomidor/srednespelye-sorta/fakel.html. Date of appeal: $02 / 14 / 2020$. (russian)

[14] The development of vegetable growing in the Russian Federation: status and prospects. Moscow: Rosinformagroteh. 2010. 224p. (russian)

[15] E.V. Sokolova, V.M. Merzlyakova, V.V. Sentemov. Micronutrients with Macropolis. Gavrish. 2015. No.2. P.34-39. (russian)

[16] Greenhouse workshop. Digest of the magazine "World of greenhouses". Tomatoes: technology. Moscow. 2000 . 110p. (russian)

[17] Greenhouse workshop. Digest of the magazine "World of greenhouses". Tomatoes: technology. Moscow. 2000. Iss.2. 136p. (russian)

[18] Greenhouse workshop: Technology. Digest of Tomato Club meeting materials. Moscow. 2011. 143p. (russian)

[19] Yu.B. Khushtov, Z.M. Daurov. Features of growing indeterminate tomato hybrids in winter greenhouses [Text]. Potatoes and vegetables. 2007. No.6. P.28. (russian)

[20] R.P. Gladkikh, V.Yu. Goncharenko, I.M. Gordienko, Y. Ilyushenko. The effectiveness of fertilizer aftereffect in vegetable crop rotation. Kharkov. 2012. Book 3. P.194-196. 